\title{
Part of the solution? Stakeholder awareness, information and engagement in tree health issues
}

\author{
Mariella Marzano • Norman Dandy • \\ Helen R. Bayliss $\cdot$ Emily Porth $\cdot$ Clive Potter
}

Received: 19 March 2014 / Accepted: 27 January 2015/Published online: 14 February 2015

(C) Crown Copyright 2015

\begin{abstract}
The dangers posed to wooded environments from tree pests introduced by the expansion of international trade in live plants and the continued use of wood packaging in transporting materials have been widely accepted. A lack of awareness of the issues amongst key stakeholders involved in the movement of these materials can hamper an effective response as their unaltered behaviours continue to have unintended consequences. Better communication and engagement is needed to enrol this wider range of actors, such as plant buyers, traders and woodland owners, in preventative action or mitigation of tree pest impacts. However, as this review paper shows, current published evidence on awareness levels and effective engagement methods is limited, and lessons must be
\end{abstract}

M. Marzano $(\bowtie)$

Forest Research, Northern Research Station, Roslin, Midlothian EH25 9SY, UK

e-mail: mariella.marzano@forestry.gsi.gov.uk

N. Dandy · E. Porth

Forest Research, Alice Holt Lodge, Farnham, Surrey GU10 4LH, UK

e-mail: Norman.dandy@forestry.gsi.gov.uk

H. R. Bayliss - C. Potter

Centre for Environmental Policy, Faculty of Natural

Sciences, Imperial College London, South Kensington

Campus, London SW7 1NA, UK

e-mail: helenrbayliss@gmail.com

C. Potter

e-mail: c.potter@imperial.ac.uk sought from research into other closely related issues such as invasive plants. We provide a summary of this available evidence, related to key stakeholder groupings, their levels of awareness and current modes of information provision and reception. It show what can at best be described as mediocre levels of awareness, and highlights the role of traditional media, such as television and newspapers, as sources of information. It further notes the urgent need for research to more fully map the tree health stakeholder landscape and to further our understanding of how to increase awareness and effect changes in behaviour.

Keywords Tree health - Stakeholders - Pests · Knowledge $\cdot$ Communication $\cdot$ Awareness

\section{Introduction}

It is now widely recognised that biosecurity threats to trees, woods and forests from the trans-boundary movement of pests and diseases (hereafter, tree pests) have increased in recent years due to the expansion of international trade and tourism (Everett 2000; Webber 2010; Perrings et al. 2010). While tree pests often spread naturally and a number of ecological factors contribute to the abundance and extent of pests once established, human activities such as the movement of plants and wood products along trade routes play an important role in the international and national spread 
of pests (Gilbert et al. 2003). The primary means through which forest pests are introduced into new environments previously free of infestation or disease are imports such as seeds, seedlings, tubers, and live plants (USDA 2005; Brasier 2008; EPPO 2012; Liebhold et al. 2012) as well as wood and wood packaging (Haack 2001, 2006; Brockerhoff et al. 2006; Ciesla 2011; Stenlid et al. 2011).

The international trade in live plants (known colloquially as 'plants for planting') involves large scale movements of material for the agricultural, forestry and horticultural industries, but is estimated to be responsible for $70 \%$ of tree pests entering the US alone (Liebhold et al. 2012). The motivations, behaviour and actions of a very wide spectrum of actors, ranging from traders to consumers, are implicated here and thus likely to be key to any future attempts to improve plant biosecurity (Stenlid et al. 2011; Niemiera and Von Holle 2009; Cushman and Meentemeyer 2008; Johnson et al. 2011). The nursery trade and the large numbers of domestic plant buyers (both amateur and professional) that it serves are already implicated in recent pest introductions such as Oak Processionary Moth (Thaumetopoea Processionea) and Ramorum blight (Phythopthora ramorum) to the UK, for instance (Tomlinson et al. 2009; Potter et al. 2013).

While generating considerable economic value, this trade is widely regarded as a high risk pathway for tree pests (USDA 2005; EPPO 2012; Liebhold et al. 2012). These risks have led some to call for a ban on trade in mature plants (Brasier 2008), though the consensus view appears to be that "a balance has to be struck between the rights of nations to restrict the spread of agents that will harm their tree-based industries and ecosystems and the risk of this being used as a barrier to free trade" (Boyd et al. 2013: 826). The diversity and volume of plants that are traded has consistently increased along with the capacity and speed of their transport. This, combined with the large size of some traded trees (in Europe-often with soil) and continual variation in their country of origin and route to market, can impact significantly on the effectiveness of import inspections (Smith et al. 2007; García-Llorente et al. 2008; Hulme 2009; EPPO 2012; Webber 2010; Liebhold et al. 2012). Pests that have moved along this 'plants for planting' pathway are thought to have contributed to biodiversity loss, reductions in ecosystem service functioning (e.g. watersheds, carbon storage), losses in economic value (e.g. lower timber value, reduced aesthetic value) and social value (e.g. changes to landscape) (Brasier 2008; Boyd et al. 2013; Holmes et al. 2009; Aukema et al. 2011; Liebhold et al. 2012; McFarlane et al. 2012). However, Smith et al. (2007) warn that there is not necessarily a direct relationship between growth in trade and increase in pests, noting that a few commodities may be responsible for many pest introductions.

A critical fact here is that the vast majority of introductions are unintentional, pests often being present on plants and/or their substrates without the knowledge of the stakeholders involved in transporting, importing or planting them. In order to secure future forest health it is clearly important that key stakeholder groups are able and willing to take part in preventative action (e.g. surveillance, biosecure buying, transport and trading practices) or mitigation (eradication and containment) of tree pest outbreaks. The need to address unintentional spread has been identified by a number of studies (e.g. Webber 2010; Dehnen-Schmutz et al. 2010), which go on to advocate raising awareness of pests among the key stakeholders along pathways in order to reduce their movement by improving the biosecurity of their behaviours and practices. Raising awareness about tree pests and disease should, it is argued, also increase the overall effectiveness of management responses to established pests (e.g. Alpert and Colton 1999; Bardsley and Edwards-Jones 2006; Brasier 2008; Stenlid et al. 2011). Improved awareness among key professionals, consumers and residents can underpin more successful early detection programmes, such as in the case of the First Detector volunteer programme (Gupta 2010). Greater awareness of tree pest impacts could also increase overall desire to participate in or otherwise support management programmes that involve potentially drastic eradication measures such as felling of host species or chemical spraying (Brockerhoff et al. 2010; Quarles 2008). Knowledge and awareness can influence attitudes and lead to changes in practices that may be culturally embedded such as the movement of firewood, complete with wood boring pests, within and across counties or states during recreational camping trips in the US (Brockerhoff et al. 2010; Runberg 2011). Pest awareness is the focus of this paper.

As McFarlane et al. (2012) have noted though, knowledge about a risk is very seldom a good 
predictor of how individuals will respond. Available evidence suggests that awareness and perceptions of risk, and subsequent behaviour, will often be influenced by a variety of social and psychological factors including social relationships and networks, trust in institutions and expertise to provide the 'right' advice, personal experience, perceived control over the hazard, affect and emotions (i.e. an individual's intuitive and automatic response to a stimulus experienced as a good or bad feeling), as well as values and worldviews (Boholm 2003; Slovic et al. 2004; Wachinger and Renn 2010). Subjective norms or perceived social pressures are also influential. Normative communication with messages highlighting societal opinions from friends, family, peers, law enforcers on what they should do can increase their inclination to comply with the norm (Ajzen 1991; Aipanjiguly et al. 2003). McEntee (2007) also highlights the importance of community participation in outbreak management and the use of engagement tools that encourages positive interaction between officials, scientists, communities and the media rather than 'top-down' public education approaches that seek to inform rather than engage. However, a starting point for better risk communication and engagement is an understanding of current levels of pest awareness within and between the different stakeholder communities with an interest in, or impact on, tree health.

Currently, there is little published evidence on these issues. In this paper we identify the main stakeholders concerned through a review of published work on levels of pest awareness and understanding within these key groupings. In addition to exploring tree pest awareness, we also review studies that show where stakeholders get information from, how they prefer to receive it and the effectiveness of information provision in changing behaviour. Given the limited evidence relating directly to invasive tree pests, we also draw on published analyses of stakeholder pest awareness in two closely related areas: (1) native tree pests where increasing impacts from outbreaks of these pests have warranted social investigations into pest awareness and attitudes towards management (2) awareness of invasive plants more generally. These two areas provide important insights into pest awareness, highlighting how it is linked to actions and acceptability of management options.

We focussed our review on two sets of evidence: (1) the awareness and knowledge of different stakeholder groups regarding the existence of pests and diseases and their impacts and, where available, actions likely to be taken; and (2) engagement activities. This second topic represents a particularly large area of research so we have focused specifically on information sources, preferred formats for engaging or for receiving information and the effectiveness of information provision or awareness raising initiatives.

\section{The emerging stakeholder landscape for tree health}

The number of organisations, businesses and individuals with a stake in preventing new tree pest introductions is already large and likely to increase in the years ahead (Dandy et al. 2013). These range from government bodies and agencies with responsibilities for tree health and plant biosecurity through to the private businesses, commercial enterprises and landowners in the forestry, arboricultural and nursery sectors. Finally, there is the plant-buying and countryside-visiting public. Their decisions about what plants to buy and where to source them from may increase the risk of a new introduction or facilitate the spread of a pest that has already become established. Taking this stakeholder mapping as our starting point, we identified 23 studies on their awareness and knowledge that were deemed relevant to the review (Table 1). Of these, eight related specifically to tree pests; the other 15 studies were drawn from the wider areas of invasive plant and agricultural pest management. Most of the studies on tree pests focused on beetle species native to the study areas; three referred to the mountain pine beetle Dendroctonus ponderosae and two to the spruce beetle Dendroctonus rufipennis. Only one study (Hurley et al. 2012) explored non-beetle tree pest species, specifically the sirex woodwasp, Sirex noctilio. We have organised the evidence into categories of stakeholdership for ease of presentation, but recognise that these categories are not homogenous entities and that there will be differences within sectors. However, the actors within each of these stakeholder groups are critical to the prevention, detection and management of tree pests and to ensuring the future health of our trees. 


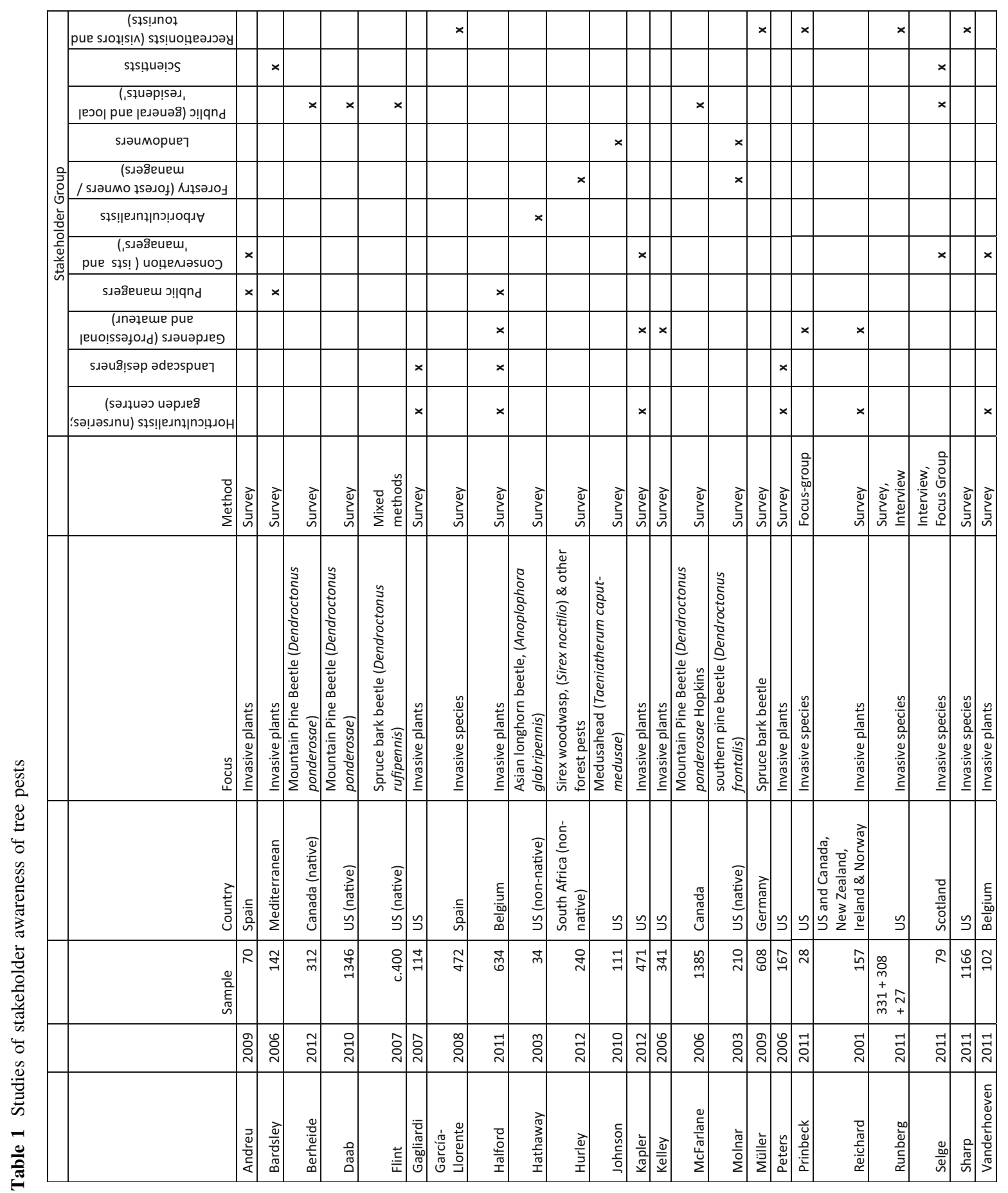


Nursery and horticultural professionals

The nursery trade is by definition heavily involved in the international live plant trade and might therefore be expected to have some awareness of the risks associated with trade pathways and practices. Although we found no studies that explored levels of awareness of tree pests within the horticultural trade, we identified five studies that assessed levels of awareness of invasive plants among nursery staff and horticultural professionals. Peters et al. (2006) surveyed members of the Minnesota Nursery and Landscape Association, including wholesalers and retail nurseries, landscape designers, installation and maintenance firms and garden centres $(\mathrm{n}=167)$. While the majority of respondents felt that it was their responsibility to educate consumers regarding invasive plants and would try to guide customers away from potentially harmful species, only $69 \%$ said they would not sell the plant. Fifty-seven percent said they would not sell a popular but potentially invasive plant even if their competitors were selling it. Halford et al. (2011) surveyed 634 nursery workers, public greenspace managers, landscape architects and amateur gardeners in Belgium. Forty five percent of nursery workers did not think the withdrawal of invasive plants for sale would threaten their business, yet $40 \%$ of nursery staff were considered to have a low level of knowledge about invasive species. The authors found that $80 \%$ of invasive plants were still available on the market based on a review of surveys and horticultural catalogues. The authors also found that horticultural professionals and gardeners were most likely to be aware of, and concerned about, invasive plants as many had experienced firsthand problems from invasives in their own work.

In Iowa, Kapler et al. (2012) conducted another survey of professional horticulturalists, conservation professionals and master gardeners. Most of the participants were able to respond appropriately to an open question asking for a definition of an 'invasive plant'. However, conservation professionals were the stakeholder group most likely to identify invasive plants as non-native. Most respondents agreed that invasive plants are a 'problem', including $79.3 \%$ of conservationists, $31.7 \%$ of gardeners and $56.6 \%$ of horticulturalists. Just over $50 \%$ of respondents agreed or strongly agreed that invasive plants are not necessarily bad plants.
Similarly, Gagliardi and Brand (2007) surveyed 114 members of the Connecticut Nursery and Landscape Association (CNLA) on attitudes towards, and knowledge of, invasive plant species as well as preferred management measures. Participants were asked if they considered themselves knowledgeable about invasive plants and $80.4 \%$ agreed or strongly agreed that they were knowledgeable. Researchers then questioned respondents as to whether they worked with the following plants and considered them invasive: Norway maple, Japanese barberry, Butterfly bush, Winged euonymus and Japanese silver grass. Only the Butterfly bush is not currently considered invasive in Connecticut while Japanese silver grass is listed as potentially invasive. Of these species $50.9 \%$ of respondents believed that Norway maple is invasive, $54 \%$ for Japanese barberry, $59.3 \%$ for Winged euonymus, $14.5 \%$ for Japanese silver grass and $8.1 \%$ for Butterfly bush. A majority of those surveyed $(63.8 \%)$ felt that the state government should have responsibility for regulating invasive plants. When asked about different forms of regulation, more participants were supportive of a ban on plants that are not economically important $(76.3 \%)$ rather than plants that do have an economic importance $(32.8 \%)$. More than $50 \%$ of those surveyed believed that even if they did not stock invasive plant species, consumers would buy them elsewhere. CNLA members were more willing to voluntarily remove invasive plants if they were to receive credit for doing so, such as earning 'environmentally friendly' credentials that could be used in marketing and promotion. Interventions such as taxation on invasive plants at the point of sale are generally not supported, although many participants $(67.5 \%)$ responded positively to the potential alternative of genetically altered sterile plants.

In a survey on awareness of invasive plant species in Belgium, $58 \%$ of horticultural professionals $(\mathrm{n}=102)$ said they were aware of invasive plants, but only $42 \%$ stated they had general knowledge of such plant species (Vanderhoeven et al. 2011). Sixtynine percent of horticultural professionals stated that they were aware of the geographical origin of the plants they sold. A high proportion of horticultural professionals ( $81 \%$ ) felt that they did not have enough information about invasive species (Vanderhoeven et al. 2011). 
Forestry/arboricultural professionals

Forestry is a large and dynamic sector made up of government, private and non-governmental sector organisations focussed on the management of trees, woods and forests. Tree health awareness and knowledge should be high given the range of activities that have implications for tree health and the potential vulnerability of the woodland resource to tree pests. The forestry sector can be implicated in the movement of pests along pathways (transporting timber, moving equipment and other infected material), take on a governance function in setting and enforcing tree health-related roles and regulations and play an important role in dissemination information and knowledge exchange through established social networks (Dandy et al. 2013). The forestry sector is also more likely to have the required knowledge and skills to engage in preventative measures, surveillance activities or to deal with an outbreak once it occurs (Dandy et al. 2013).

Nevertheless, only two studies were retrieved that focused on awareness of tree pests among forestry and aboricultural professionals. Hathaway et al. (2002) studied the awareness and knowledge levels of tree care professionals in Chicago in relation to the Asian Longhorn beetle (ALB; Anoplophora glabripennis). Respondents were given questions relating to shape and size of ALB exit holes, where the sawdust is likely to be located and current methods of eradication. The answers revealed that $35 \%$ of respondents were considered 'informed' in that they were able to answer all four multiple choice questions on diagnosing ALB correctly but $59 \%$ were categorised as 'inconclusive' in that they only answered two or three questions correctly. The authors note that it is important for tree care professionals to be completely informed, particularly in detecting tree pests.

In South Africa, 240 forestry professionals (including private timber growers, plantation managers, contractors and researchers) were surveyed to identify current perceptions and knowledge of the Sirex woodwasp (S. noctilio) and other forest pests (Hurley et al. 2012). The authors found a high knowledge of general forest pests among participants, although levels of awareness on specific pests varied based on their relevance to the professional's job. More specifically, the authors report that most participants had a basic knowledge of the trees most infested by the
Sirex woodwasp and the age of trees infested. They were also mostly knowledgeable about areas where the pest had been detected and means by which the pest can spread with $79 \%$ identifying pallets, $89 \%$ flights and $93 \%$ roundwood although only $60 \%$ knew that the Sirex woodwasp does not spread through bark. However, less than $50 \%$ of respondents were able to identify the pest or symptoms relating to infestation.

\section{Landowners}

Landowners with responsibility or control over the use, development and management of land that hosts trees are a critical stakeholder group, particularly in the private sector, with the potential to contribute significantly to surveillance, prevention, eradication and containment efforts (Dandy et al. 2013). For example, management practices can facilitate or hinder the movement of tree pests while early detection of pests on private land could be instrumental in preventing its spread.

Only two studies were retrieved that focused on levels of awareness among landowners, and only one of these is related to a tree pest, which is native to the study area. Molnar et al. (2003) surveyed 210 nonindustrial landowners in Southern US with respect to awareness of the southern pine beetle (SPB, Dendroctonus frontalis). Sixty percent of landowners with $>85$ acres stated they were very aware of SPB as a source of timber loss. Only $32 \%$ of landowners with between 15 and 84 acres stated they were very aware and $15 \%$ of landowners with $<15$ acres. One-third of the respondents said they did not look out for SPB problems, although only $5 \%$ of landowners with $>85$ acres did not actively look for SPB as opposed to $39 \%$ of landowners with $<15$ acres. Larger landowners stated they looked for beetle damage, although they tended to rely on others to identify problems; $68 \%$ of respondents stated that they did not take any preventative actions to limit losses by Southern Pine Beetle.

Johnson et al. (2011) investigated the perceptions of ranchers in the western United States in relation to the invasive grass known as 'Medusahead' (Taeniatherum caput-medusae). The study included landowners both with and without experience of Medusahead to assess whether this influenced their perceptions and behaviour. Two key issues raised by this study are that invasive plant species are often not recognised as a problem until it is too late, and that they often spread 
from neighbouring land that has already been infested. Ranchers with experience of Medusahead unsurprisingly had greater awareness of the species although the authors note the potential bias over who chose to respond to the survey. Nevertheless, the authors highlight concerns over awareness levels of those landowners who have not experienced the negative impacts of Medusahead.

\section{Ecologists and environmental managers}

No studies were found that assessed levels of awareness of tree pests among ecologists or environmental managers, although three studies relating to invasive plants and one to invasive species more generally were identified. Halford et al. (2011) found that all of the 34 surveyed green-space managers in Belgium were aware of the invasive plant species problem, with $82 \%$ stating that they had a general knowledge of the issue. In the Mediterranean, 142 respondents (including between 30 and 40 ecologists) based in Crete, Mallorca and Sardinia, were surveyed on their perceptions of impacts of exotic invasive plant species and willingness to support management options (Bardsley and Edwards-Jones 2006). One of the findings highlighted that introductions of exotic plant species had been happening for centuries through trading and colonisation. Thus, concern over newer invasions are influenced by historical values attached to exotic plants, some of which were wrongly identified as native, culminating in a wide-spread acceptance of "human-induced changes to the landscape" (p. 208). The authors suggest that education programs are needed to highlight the potential negative impacts of exotic species.

In Spain, 70 environmental managers from public bodies dealing with forestry, nature conservation, water management and coastal protection, were surveyed on their perceptions of invasive plants and related management activities (Andreu et al. 2009). Although the study does not focus specifically on awareness and knowledge, the authors found that managers identified 193 plants they considered to be noxious, which they suggest indicates high levels of awareness of the presence and impacts of such plants. Another study not directly assessing awareness investigated perceptions and attitudes of ecology professionals and members of the public (including conservation volunteers) relating to invasive species in Scotland (Selge et al. 2011). This qualitative study found that the attributes of a landscape could influence people's attitudes towards species that were felt to negatively impact that place.

\section{Gardeners}

Gardeners are a key stakeholder due to their purchasing power (Kubeck 2008). No studies were found that examined levels of awareness of tree pests among gardeners, but four studies looked at awareness of invasive plants. Kelley et al. (2006) surveyed 341 visitors to the Philadelphia flower show in order to better understand more about consumer attitudes towards, and awareness of, potential problems associated with invasive plant species. Of those 341 consumers, $81.5 \%$ stated that they were aware of nonnative invasive plants. However, even though the majority of study participants were familiar with the characteristics that make a plant invasive, many still preferred to purchase landscape plants with invasive features. For example, the authors listed characteristics that would be considered attractive to gardeners but could contribute to invasiveness. They found that $78 \%$ would consider buying plants that are adapted to where they live, $62.4 \%$ were interested in a long flowering and fruiting period while $47.1 \%$ found plants producing fruit that encouraged birds and animals into the garden appealing. Awareness can be linked to buying practices but only $40.1 \%$ reported that they had invasive plants in their garden with $33.5 \%$ responding that they didn't know.

Reichard and White (2001) report on a survey of 157 members of internet horticultural discussion groups. They found that there was a link between levels of awareness and familiarity with invasive plant species and the purchasing of invasive plants: $92 \%$ of participants who said they were aware of invasive species also stated that they would not buy invasive species compared to $52 \%$ of participants who were not familiar with the issues around biological invasions. When asked if discussion group members would seek out a listed invasive species elsewhere if it was not sold in their nursery, $92 \%$ stated that they would not.

Prinbeck et al. (2011) examined awareness around a range of invasive species by holding focus groups with gardeners, hunters, fishers and boaters. A common attitude among all interest groups was that 
preventative or control measures may cause more environmental harm than the invasive species themselves and that the battle against invasive species may be futile given wider global environmental changes that are beyond an individual person's control. There were also perceptions that regulations are often weak or not enforced, allowing, for example, invasive plants to be sold in garden centres. The results of these focus groups indicate that people are generally uninformed about invasive species. In particular, gardeners highlighted a need for more information, not only about how to identify and tackle invasive species but also what to do with them once they have been removed.

In Halford et al's (2011) survey, amateur gardeners in Belgium were questioned on levels of knowledge, awareness and concern about invasive ornamental plants. Eighty six percent of gardeners answered positively when asked whether they knew what an invasive plant was. Moreover, $88 \%$ believed that invasive plants were an important issue while $83 \%$ felt concerned about the issue. A further $86 \%$ said they would prefer to shop at nurseries that did not sell invasive plants. Most agreed that they needed more information.

\section{Local residents}

Three studies were identified that examined levels of awareness among residents living in or near areas affected by native tree pests the impact of which is worsening, and a fourth that explored awareness of invasive plants following an outbreak of a tree pest. McFarlane et al. (2006) conducted a mail survey of 1,385 residents living in or near two national parks in Canada to understand more about public awareness of, and attitudes towards, Mountain Pine Beetle (Dendroctonus ponderosae Hopkins, MPB) in the area. They found that while most of the residents (nearly $100 \%$ of participants) had heard of the MPB, basic knowledge about the provenance of MPB, where it can be found and the age range of pine species favoured by MPB was largely lacking. However, the majority of residents did correctly identify some basic facts, such as that MPB can be transported in firewood, causes visible damage and is prone to population fluctuations. The authors note that overall, residents viewed the presence of MPB in the national parks negatively and were in favour of management measures such as sanitation felling, the use of pheromone traps and prescribed burning in infested areas. The use of chemicals and control activities in un-infested but vulnerable areas as a precautionary measure, were not supported. Berheide (2012) also studied attitudes towards MPB in two communities in British Columbia, Canada that were both impacted by the pest; one of the communities was more dependent on forest resources than the other. Overall, 312 surveys were conducted with community residents. Residents of the forest-dependent community knew more about the MPB outbreak and its management than residents of the less dependent community. Nevertheless, the majority of respondents from both communities $(60 \%)$ stated that they knew little or nothing about MPB despite surrounding forests being heavily infested. Interestingly, more respondents in both communities perceived the MPB outbreak as a result of human mismanagement (43\%) than as a natural phenomenon (38\%). Flint (2007) emphasised the emotional attachment people can have to trees in their garden or local area, as well as the importance of landscape amenity. A spruce bark beetle (Dendroctonus rufipennis) outbreak in Homer, Alaska led to the large-scale loss of trees and was described as devastating by the local community with fears about what the area would look like in the future. A study (Hunter 2011) on local residents' responses to the loss of street trees from Emerald Ash Borer in Michigan did not actively assess levels of awareness but the study does highlight that proximity to tree loss had an impact on residents increasing their engagement with stewardship activities.

Daab and Flint (2010) investigated awareness of the spread of invasive plants following an outbreak of MPB in Colorado (Daab and Flint 2010). The authors surveyed 1,346 residents across nine communities in north-central Colorado. Due to the relatively high media coverage of invasive plants in this area and active outreach including education programmes, the authors hypothesised that awareness of invasive plants would be high. Indeed, $85 \%$ stated that they had heard or read about invasive plants in their area. However, respondents were less aware of the invasive plants that were specifically targeted by management initiatives in their counties. Residents indicated a concern about the consequences of invasive plant species on the ecosystem and native flora and also agreed that they had a personal responsibility for protecting against invasive plants. 
Outdoor recreationists and tourists

Visitors to the outdoors can unintentionally spread pests via their shoes, clothes and vehicle tyres. Four studies, including one on tree pests, were found that examined levels of awareness among outdoor recreationists and tourists. No studies were identified that assess the awareness levels of sea and air passengers relating to tree pests and diseases despite this being identified as an issue (Putulan et al. 2004). Müller and Job (2009) explored tourists' attitudes towards the native spruce bark beetle (Ips typographus) in the Bavarian Forest National Park, Germany. The survey in the national park consisted of 608 members of the public identified as tourists (i.e. not local residents). Seventy-five percent of respondents had already seen forests typically affected by bark beetles and $63.5 \%$ correctly identified bark beetles as the primary causal agent of tree mortality in the national park. Importantly, results indicated that participants did not believe that bark beetle had a negative impact on tourism and, overall, the findings indicate that there was a slight preference for allowing the bark beetle to exist in the national park. Those who felt some attachment to the national park were more in favour of allowing the bark beetle infestation to run its course. The authors also found that higher levels of knowledge about the bark beetle and its potential function in ecosystem renewal also resulted in a more positive attitude towards the species.

Runberg (2011) carried out a study on campers in the US Pacific Northwest to identify levels of awareness, knowledge and attitudes towards invasive species, particularly in the context of transporting firewood from home to the campsite. Two surveys $(\mathrm{n}=331$ and $\mathrm{n}=308)$ and 27 semi-structured interviews were conducted at selected camping grounds. Of those who took part in the survey, $66 \%$ were able to identify the correct definition of an invasive species. The author also found that while most of the campers interviewed were able to identify invasive species that have impacted on their activities, few were knowledgeable about pest pathways or specific vectors, such as firewood movement. Campers were sceptical that the movement of firewood presented a biosecurity risk, believing that while insect pests do infest wood, campers do not tend to carry firewood over long distances. Another study in the US (Cumberland Island National Seashore, Georgia) examined public attitudes, knowledge and preferences for management options of invasive alien species (Sharp et al. 2011). Visitors $(\mathrm{n}=1,166)$ to the island reserve were surveyed. Generally, visitors were found to be slightly aware of invasive species but were less aware of the impacts of specific invasive species in the national park. This study also recognised that the eradication of invasive species can be controversial when visitors' ideals about landscape aesthetic differ from that of conservationists and managers. Tourists visiting the Doñana wetlands in Spain were found to have relatively low knowledge of invasive exotic species, but did recognise species featured on information boards. Tourists were found to have little awareness of the impacts of invasive species generally, with $60 \%$ potentially willing to introduce a non-native species into the environment if it resulted in an economic or recreational benefit to them (García-Llorente et al. 2008).

Overall, this review highlights that self-reported awareness of tree pests and other invasive species varies among stakeholder groups, but that even when many respondents report awareness this is very rarely in-depth. Awareness of potential pest impacts is low for example, as is awareness of links to stakeholder behaviours.

\section{Information provision and stakeholder engagement}

We identified twelve studies that investigated issues around the provision of information and other stakeholder engagement methods. Of the twelve studies identified, five related specifically to tree pests and focused on individual species.

From where do stakeholders get information about pests?

Hurley et al. (2012) assessed the 'level of exposure' of forestry professionals to nationally-coordinated media communication about the Sirex woodwasp in South Africa. Seven media were used within the initiative, five of which rated very highly in terms of informing respondents: field days ( $90 \%$ of sample had been 'informed' about the woodwasp through this source), magazines/newspapers (86\%), industry newsletters (89 \%), pamphlets/pest cards $(86 \%)$ and posters 
(84\%). The internet and websites were identified as the least used media but were still used by over half the respondents $(51 \%)$. The authors found that geographic location of respondents and the type of job held by the forestry professional as well as length of time in service influenced which media avenue they were exposed to. For example, those living in areas where Sirex woodwasp was present were more likely to have learned about the pest through magazines and newspapers, while those with longer experience in their field had greater chance of coming across 'official' information about the woodwasp.

Hathaway et al. (2002) studied awareness of the Asian longhorn beetle among tree care professionals in Chicago and found that, of the 34 survey returns from tree care companies, $85 \%$ of respondents were informed through television programmes but $65 \%$ received information from the United States Department of Agriculture, which was perceived to be more credible. The internet was only used by $1 \%$ of respondents.

Molnar et al. (2003) identified the 'state or county forester' as the most important source of information for forest landowners in the Southern Pine Beetle study. Owners with large holdings were also found to favour private forestry consultants, while small and medium sized landowners favoured the 'Extension Service county agent'. Other sources were less important, especially pesticide company representatives and other landowners.

The final tree pest study (Surendra et al. 2009) reported on a survey of 463 non-industrial landowners in Arkansas on their information-seeking behaviour relating to the Red Oak Borer (Enaphalodes rufulus). The authors highlighted the diverse and heterogeneous nature of this loose group of landowners in terms of their demographic characteristics and management objectives. They were able to segment the respondents into four ownership groups based on rural/urban location and main management activities and divided information sources into personal communication (e.g. agents, extension services, state and federal forestry personnel, other landowners) and mass media. The authors found a strong relationship between personal communication and group type. Personal communication about the Red Oak borer was the primary means of information source for $32 \%$ of Amenity focused rural landowners, $31 \%$ of passive rural landowners, $15 \%$ of Amenity focussed urban landowners and $17 \%$ of passive urban landowners. They did not find a significant relationship between group type and mass media as a source of information with this medium being used by $25 \%$ of amenityfocused rural landowners, $8 \%$ of passive rural landowners, $22 \%$ of amenity focussed urban landowners and $19 \%$ of passive urban landowners. The authors highlighted that mass media can raise awareness of tree pests but personal contacts are more effective at promoting behaviour change.

Studies into the sources used to find information about invasive plants suggest that different stakeholder groups favour different sources. For example, $68 \%$ of consumers in horticultural-oriented internet discussion forums that were familiar with the issues around invasive plants had read about them in magazines and newspapers (Reichard and White 2001), while plantbuyers surveyed by Kelley et al. (2006) first found out about invasive plants via television $(27.4 \%$ ), newspapers, magazines and books (19.8\%), friends, family and neighbours $(9.4 \%)$, garden clubs $(7.5 \%)$ and garden centres and nurseries $(7.1 \%)$. Daab and Flint (2010) found that the most common source of information on invasive plants for residents in North Colorado was newspapers $(67.8 \%)$, followed by 'word of mouth' (50.3\%), 'my own observations' $(49.5 \%)$ and the 'County extension office' (38.2\%). Twelve further sources of information were identified by this study. However, the authors found that information sources most commonly used are not currently assisting residents to identify invasive plants in their area. Respondents from the horticulture sector in Minnesota used (from a limited selection) growers/ wholesalers, industry publications and the University of Minnesota Extension Service to inform them about the plants they sell (each used by approximately a quarter of respondents), while scientific literature was used by about one-sixth of respondents (Peters et al. 2006). Similarly, surveys of tree fruit and small grains producers in Utah (Alston and Reding 1998) identified that the local extension service was the most preferred source of information on pest management. 'Other growers' and 'yourself/trained employee' were also identified as important information sources, along with 'agricultural chemical dealers' for small grain producers. Private crop or pest consultants were identified as information sources by only a few respondents. Most members of the Connecticut Nursery and Landscape Association informed themselves 
about invasive plants through trade journals and professional organisations (Gagliardi and Brand 2007), while a study in Iowa (Kapler et al. 2012) among conservation professionals, master gardeners, professional horticulturalists and woodland landowners found that the most common sources of information about invasive plants were newspapers, magazines or books $(82.3 \%)$, educators or workshop/lectures $(81.7 \%)$, conservation professionals $(74.8 \%)$, colleagues $(63.8 \%)$, and the Internet $(60.8 \%)$; plant retailers or nurseries were the least common source of information.

In which format do stakeholders prefer to receive information?

Some studies explicitly assessed stakeholder preferences for the format in which they would like to receive information about tree pests. Consistently among these is a stated preference for printed materials, often those produced within the 'industry'. Molnar et al. (2003) found that for forest landowners the most preferred format to receive information was through printed materials such as bulletins and newsletters. Owners of larger land holdings noted some other formats were liked, particularly direct contact with public agency foresters, however owners of smaller forests rated all other formats of information very low. Ranchers in Johnson et al.'s (2011) study on attitudes towards the invasive grass 'Medusahead' indicated that they preferred to receive information either through pamphlets and bulletins or via face-to-face communication with a management specialist. Internet based resources were, again, the least preferred methods of communication. Tree care professionals in Chicago also expressed that printed bulletins was their most preferred method to receive information about Asian Longhorn Beetle (Hathaway et al. 2002). In this study, the internet once again rated lowly with just $14 \%$ of respondents saying they used it to get pest related information. Face-to-face communication is often considered an effective format via which to deliver information and engage with people (Kruger et al. 2010).

The effectiveness of information provision

It is now widely accepted that monitoring and evaluating (M\&E) the impacts of different approaches to communication on behaviours - that is, which approaches work best with different stakeholder groups-is essential in order to enable improvements in its design and delivery (Sharp et al. 2012). However, it is also acknowledged that identifying causal factors related to different communication and engagement approaches, such that it is clear whether behaviour change is directly linked to tree health communication, is notoriously difficult to achieve and such evaluations are rare (Sharp et al. 2012). We found only one study that attempted to evaluate the effectiveness of an information provision campaign about tree pests on stakeholders. Runberg (2011) conducted a two-part survey before and after a multi-faceted information campaign to inform the public, particularly campers, of the risks of moving firewood. The campaign involved campground materials (posters, flyers, playing cards, frisbees), roadside billboards, online material (www.dontmovefirewood.org; electronic campsite reservation notification) and newspaper articles featuring information on pest species vectors, impacts and good practice. The author noted however that the communication strategy did not take into account beliefs or knowledge of campers relating to invasive pests and firewood, prior to designing the communication materials. Access to information during the campaign was found not to increase campers' concern or knowledge about invasive species. However $61 \%$ of post-campaign respondents who had been exposed to information agreed that they would change their firewood practices. Another study (McEntee 2007) examined modes of engagement in relation to two case studies of moth eradication through aerial spraying in Auckland, specifically the White-spotted Tussock Moth Orgyia thyellina and the Painted apple Moth Teia anartoides. While there was no evaluation of the engagement methods post-campaign for either case study, McEntee (2007) was able to assess the efficacy of the Ministry-run campaigns through the level of conflict the campaign created with local communities and officials and then reported in the media. The author found that White-Spotted Tussock Moth campaign involved a much greater level of engagement through sustained information provision, consultation and community involvement in surveillance efforts. While there were some criticisms of the campaign, the varied methods of engagement facilitated community support for the programme. In contrast, the Painted Apple Moth eradication 
campaign was much less inclusive, focussing on education through advertising campaigns rather than direct engagement, which resulted in greater conflicts over eradication methods.

\section{Discussion}

Levels of awareness

Despite the fact that a lack of awareness of pests and diseases among key stakeholders has been repeatedly identified as a critical biosecurity problem and driver of biological invasions (Stenlid et al. 2011; DehenSchmutz et al. 2010; Webber 2010) it has received little dedicated research attention and analysis. We found only limited evidence on stakeholder awareness of tree pests, and many of these studies were related to species that were native to the area of study. We have therefore also looked to other fields, particularly the larger body of work carried out on invasive plants generally. The few studies focused directly on tree pests, are spread widely across the various key stakeholder groups and the focus of these is often on a single species. We located only studies of beetles: no studies of pathogen tree pests were identified. Considerably more evidence is available relating instead to invasive plants. Low levels of awareness related to invasive plant species are of interest because they may be considered indicative of wider levels of awareness. Having noted that, it is important to recognise that invasive plants (especially ornamentals) are often introduced to new areas deliberately. In contrast the introduction and spread of tree pests (native and nonnative) is generally unintentional, as a contaminant of traded goods or firewood, and is unlikely to be a key focus for stakeholders. Thus the focus of awareness (or lack of) shifts from the unknown presence of an invasive pest to a species potentially unknown invasiveness. The underlying argument is still the samethat if the actor (stakeholder) involved were 'aware', their action would be different.

Should we expect differing levels of stakeholder awareness between insect and pathogen pests? Intuitively it seems likely—some insects are large enough to see, pathogens are not as obvious - but we currently have no direct evidence on which to base a comparison. Awareness-raising relating to insects and pathogens must necessarily take different forms and become relevant at different points in time as outbreaks evolve. Insects can be identified directly and (potentially) be located before damage to trees occurs. For surveillance purposes, pathogens, in contrast, are usually identified by the emergence of disease symptoms. These differences may require distinct approaches to awareness raising, surveillance training, and guidance regarding subsequent behaviours.

Similarly we can also ask, should we expect different levels of stakeholder awareness between 'native' and 'non-native' pests? It's not possible to draw strong conclusions here, primarily due to the lack of studies of awareness of non-native tree pests for comparative purposes (only two studies, Hathaway et al. 2002; Hurley et al. 2012). There is no clear reason to assume higher levels of awareness of native tree pests, despite their longer presence in local environments (other than perhaps among those professional stakeholders managing them). In fact, awareness of non-natives is perhaps likely to be greater, due to the media coverage they receive and their cultural significance. Other drivers of awareness, such as the visible symptoms and impacts of pests, may be considered broadly similar for native and nonnative pests, even if sometimes more substantial in scale. For effective biosecurity we may desire higher levels of awareness of non-native pests, so as to avoid unintentional spread as already discussed. This may lead policy-makers to focused awareness-raising efforts on non-natives. Stakeholder attitudes towards the management of native and non-native pests may, however, be different. Intuitively we may expect less support for management of native pests (especially their eradication), especially among environmentally conscious stakeholders. Some evidence supports this (e.g. Müller and Job 2009) although it has not been widely explored.

Taken as a whole, the evidence identified by this review reveals varied levels of awareness across stakeholder groups and suggests somewhat superficial knowledge about tree pests and diseases. The evidence is also rather patchy with certain groups receiving more attention than others and some distinct gaps. For example, while there are some studies of forest recreationists and visitors, we identified no studies of air or sea passenger awareness. Studies from other sectors have shown that this group presents a risk and that they may not fully understand the requirements of customs officials and practices (Hall 2005) but they 
remain largely unanalysed. Another significant omission from the evidence is assessments of pest awareness among key groups at the source of invasionse.g. 'exporting' forest industry actors.

None of the studies related to nurseries and horticultural professionals focuses directly on tree pests. However, the evidence describing this group's awareness of invasive plants identifies what can at best be described as mediocre levels of awareness among a critical group. Given the apparent role of the horticultural trade in the spread of tree pests, it is a significant concern that there have been no studies to ascertain levels of awareness of tree pests among those employed in this area. Moreover, while perhaps suggesting an acceptance of responsibility to disseminate information, these studies show that horticulturalists do not believe their economic opportunities should be reduced to address biosecurity issues and this is also a cause for concern.

In some contrast, the limited evidence available relating to professionals that work in forestry, aboriculture and connected fields appears to show a good general awareness of the tree pest issue, but with lower levels of specific and detailed knowledge (Hathaway et al. 2002; Hurley et al. 2012). Given their significant stake in tree health, there is also surprisingly little evidence relating to landowners levels of awareness of the issues. What little is available suggest the rather intuitive conclusion that landowner awareness increases as their potential or actual stake strengthens, through experience of pests or the scale of their potential loss. Although there are once again relatively few studies of pest awareness within the local residents stakeholder group, those that have been done relate directly to tree pests. As with the evidence relating to other groups such as gardeners, the main finding appears to be high levels of relatively superficial knowledge. Recreationists and tourists have been reasonably well studied compared to other stakeholder groups, although most surveys have focused on invasive species more generally. Levels of awareness of this group are generally lower than among residents and gardeners, but similar to landowners.

Stakeholder engagement and implications for tree health

Stakeholder 'engagement' can (and should) encompass a wide range of activities and methods. Many reviews of stakeholder engagement (e.g. Dwyer et al. 2007) note that the provision of information alone (the core of awareness raising) is unlikely to be enough to change the attitudes, behaviours or practices of stakeholders. Rather a combination of various communication and engagement strategies is needed to facilitate changes in behaviour. Having said this, information provision is a critical element of engagement, even multi-faceted initiatives, and informationfocused campaigns remain the most common form of initiative (such as, 'Hungry Pests', http://www. hungrypests.com/; 'Don't Move Firewood' http:// www.dontmovefirewood.org/ and 'Weedbusters'http://www.weedbusters.org.nz/). Although the evidence relating to information sources is somewhat heterogeneous, with questions being asked in a variety of ways, it does represent a useful body of work. It is very much dominated by survey research, with very few qualitative studies.

One problem with this literature is that studies do not always effectively distinguish between analysis of the source of information (e.g. friends and family or extension services) and the format in which it is provided (e.g. poster, television, internet). This is confounded by the wide variety of questions about information sources which surveys use. These can include asking respondents where they 'first heard about' a pest, where they 'would seek information about' a pest, and/or how they would 'prefer to hear about' a pest. If future tree health engagement is to be effective, there is consequently a need to better understand both how different stakeholders can most easily and effectively receive information (format) and from whom it can best be received (source). Research into the former will likely be relatively simple although it would clearly need to account for the significant recent changes in communications technology. Research into the latter will be more complex and need to encompass understanding stakeholder social networks and relations of trust.

Having said this, the evidence does highlight the central role played by traditional media sources such as newspapers, magazines and television-even among professionals-although these popular modes of information provision are rarely enough to change behaviour on their own (Parks and Theobald 2011). Government and other professional advisers are clearly important sources of information and through face-to-face contact they are potentially the most 
effective at promoting behaviour change. For example, familiar examples within information provision can make it more relevant for local residents (Dwyer et al. 2007). Clearly therefore, future tree health and biosecurity initiatives should maintain these well used and familiar methods.

The mobilisation of volunteers is likely to be a very effective route through which to engage tree health stakeholders in the future. Kruger et al. (2010) and McFarlane et al. (2012) both highlight the value of a 'community champion' in promoting engagement. McFarlane et al. (2012) suggest that land managers could act as trusted 'risk promoters' using the local media to warn of the risks and consequences of an outbreak. Citizen science offers other routes to active engagement of stakeholders, especially among those less routinely involved with tree pest management (van Santen et al. 2004). As Runberg (2011: 13) states "there are far more citizens who explore the forests, rivers, lakes and rangelands than professional scientists or agency officials who are looking for new infestations. The use of public education to help increase early detection has shown to be very cost effective". The Forest Pest First Detector programme in the US is a useful example of how citizen science can be beneficial in early detection of pests (see Gupta 2010). The programme developed primarily in response to emerald ash borer (EAB Agrilus planipennis). Volunteer 'First Detectors' are usually tree professionals or interested and knowledgeable community members who apply to become part of the programme and receive training, and who subsequently act as citizen-level contact points for the wider community to report suspected tree pests. Early evaluations (e.g. Gupta 2010) highlight that two thirds of the volunteers trained have stayed with the programme. First Detector volunteers were actually the first to detect EAB in Minnesota.

There is ample research available on the opportunities and barriers to recruiting, training and motivating volunteer monitors (Bell et al. 2008; Clarke et al. 2012). Clarke et al. (2012) cite an example of a volunteer monitoring programme concerning red fire ants in Brisbane, Australia. In addition to surveillance, a range of local awareness raising activities were carried out by volunteers such as attendance at local events, presentations at schools, distribution of printed material, wearing red fire ant shirts during surveillance and displaying information on car stickers and in their windows at home. Another example of an initiative involving community volunteers are the 'Treekeepers' who volunteer for the urban 'Openlands project' in Chicago. These are 'citizen foresters' trained in general arboriculture to enhance public open spaces but also in identifying presence of insects and diseases including the gypsy moth (Lymantria dispar) and Asian Longhorn beetle (Anoplophora glabripennis) (Sacco 2004). Citizen participation in tree pest management could also enhance acceptability of management methods and trust in government and management bodies in order to reduce potential negative responses to outbreak management (van Santen et al. 2004; Flint 2006; Quarles 2008; Brockerhoff et al. 2010).

The evidence collated here suggests that the internet is the least used or preferred method for seeking information, which runs counter to a whole range of current engagement efforts that are webbased. However, due to its relatively recent development, the impact of the internet, and especially its novel uses such as social media, is likely to be underreported in the current evidence. Thus, it cannot be expected that this limited evidence-which is largely 'historical' in nature - can effectively report on the impact of these formats. Nevertheless, websites can be highly accessible and contain a great deal of information at a single location (Niemiera and Von Holle 2009), but there are drawbacks to using websites as the sole form of outreach if they are passive. In these circumstances if someone is not seeking information on biosecurity issues (i.e. using specific terms within a search engine) it is unlikely they will receive any information. However, websites can used to respond actively to relevant stakeholder choices. For example, in Australia, people searching for plant seeds on the internet are warned of regulatory restrictions against importing exotic material (Everett 2000). In a similar vein, campers in the Pacific Northwest of the United States are warned about the dangers of transporting firewood when booking campsites online. Social media and associated new technologies such as smart phone applications provide a number of opportunities for more active forms of information provision than traditional formats. For example, as part of an Emerald Ash Borer (EAB) Awareness week in the United States in May 2013, the public were encouraged to join the 'Stop the Beetle' Facebook page to participate in educational activities (FOCI Newsletter 2013). 
In the UK, a citizen science programme called relating to the horse-chestnut leaf-mining moth Cameraria ohridella (Conker tree science http://www. ourweboflife.org.uk/), developed a smartphone 'app' allowing citizens to upload photos and location via GPS. Records from 2011 indicate that nearly 10,000 people downloaded the 'app' and/or submitted records (Pocock and Evans 2013). It is likely that a combination of approaches will be necessary to reach different stakeholders. Monitoring and evaluation must become an element of future biosecurity engagement and awareness initiatives. Although outreach activities around biosecurity have been implemented in a wide range of regional contexts, little evidence has been gathered as to their efficacy, and this is a significant gap in the evidence (Kruger et al. 2009). In general, leaflets/ brochures, posters, and one-on-one or town meetings tend to be the means by which managers of pest outbreaks communicate with those who are impacted by them. However, Dwyer et al. (2007) note that some stakeholder groups may struggle with the volume of information sent to them and/or the sheer number of events they are invited to. On the other hand, McEntee (2007) also highlights the problems and conflicts that can occur if communities are informed about outbreak management without being given the chance to contribute to decision-making or management efforts. The lack of monitoring and evaluation of factors that have been successful and unsuccessful in raising pest awareness is a critical piece of missing information that could assist policy makers in determining the direction of future engagement initiatives. Having said that, Dwyer et al. (2007) discuss the difficulties of evaluating effectiveness of engagement, particularly separating changes related to the intervention from what may have happened anyway and also the time lag between raising awareness and changing behaviour.

\section{Conclusions}

Biosecurity threats to our trees, woodlands and forests necessitate action from a wide range of stakeholders, each of whom will need to be involved to varying degrees in actions to prevent the introduction or spread of pests. However, it is still unclear how much knowledge or understanding key stakeholders have about the risks involved. Our review of the literature suggests that there is limited research concerning either levels of awareness or degrees of engagement among different stakeholder groups. In particular, there is a paucity of studies focused on the horticultural sector, a key vector for tree pests and a major stakeholder for this issue. The limited evidence that is available suggests that self-reported levels of awareness vary between stakeholder groups, and that awareness is often at a general rather than detailed level. There also appears to have been limited evaluation of awareness raising campaigns to date. The studies in this review also highlight the relative importance of face-to-face contact as an engagement method. However, a lack of evidence in this area highlights the need for urgent research to establish baseline levels of awareness that will not only inform future outreach activities, but also provide an opportunity to evaluate the effects of subsequent information provision campaigns on tree pests.

Acknowledgments This paper is an output from the PERMIT COST Action FP1002 and was funded by the Forestry Commission Great Britain and the Department for Environment, Food and Rural Affairs. The authors would like to thank Trevor Fenning, Chris Quine, and two anonymous referees for comments provided on earlier drafts.

\section{References}

Aipanjiguly S, Jacobson SK, Flamm R (2003) Conserving manatees: knowledge, attitudes, and intentions of boaters in Tampa Bay, Florida. Conserv Biol 17:1098-1105

Ajzen I (1991) The theory of planned behavior. Organ Behav Hum Decis Process 50:179-211

Alpert P, Colton T (1999) Public unawareness of biological invasions by plants. Wildland Weeds, Spring: 4-7

Alston DG, Reding ME (1998) Factors influencing adoption and educational outreach of integrated pest management. J Ext 36(3). http://www.joe.org/joe/1998june/a3.php

Andreu J, Vilà M, Hulme PE (2009) An assessment of stakeholder perceptions and management of noxious alien plants in Spain. Environ Manag 43:1244-1255

Aukema JE, Leung B, Kovacs K, Chivers C, Britton KO, Englin J, Frankel SJ, Haight RG, Holmes TP, Liebhold AM, McCullough DG, Von Holle B (2011) Economic impacts of non-native forest insects in the continental United States. PLoS ONE 6(9):e24587

Bardsley D, Edwards-Jones G (2006) Stakeholders' perceptions of the impacts of invasive exotic plant species in the Mediterranean region. GeoJournal 65:199-210

Bell S, Marzano M, Cent J, Kobierska H, Podjed D, Vandzinskaite D, Reinert H, Armaitiene A, Grodzinska-Jurczak M, Muršič R (2008) What counts? Volunteers and their organisations in the recording and monitoring of biodiversity. Biodivers Conserv 17(14):3443-3454 
Berheide DW (2012) Factors influencing public support for managing the Mountain Pine Beetle epidemic. Master of Science thesis, University of British Columbia

Boholm A (2003) The cultural nature of risk: can there be an anthropology of uncertainty? Ethnos 68(2):159-178

Boyd IL, Freer-Smith PH, Gilligan CA, Godfray HCJ (2013) The consequences of tree pests and diseases for ecosystem services. Science 342:1235773

Brasier CM (2008) The biosecurity threat to the UK and global environment from international trade in plants. Plant Pathol 57:792-808

Brockerhoff EG, Bain J, Kimberley M, Knížek M (2006) Interception frequency of exotic bark and ambrosia beetles (Coleoptera: Scolytinae) and relationship with establishment in New Zealand and worldwide. Can J For Res 36:289-298

Brockerhoff EG, Liebhold AM, Richardson B, Suckling DM (2010) Eradication of invasive forest insects: concepts, methods, costs and benefits. NZ J For Sci 40(suppl):S117S135

Ciesla WM (2011) 'Forest insect and human interactions' in Ciesla, forest entomology: a global perspective. Blackwell Publishing Ltd, London

Clarke R, Aslin H, Kruger H, Bury A (2012) Volunteer monitoring in biosecurity: an issues paper. Australian Government Department of Agriculture, Fisheries and Forestry

Cushman JH, Meentemeyer RK (2008) Multi-scale patterns of human activity and the incidence of an exotic forest pathogen. J Ecol 96:766-776

Daab MT, Flint CG (2010) Public reaction to invasive plant species in a disturbed Colorado landscape. Invasive Plant Sci Manag 3:390-401

Dandy N, Porth EF, Marzano M, Potter C, Bayliss H, Maye D (2013) Working paper 2: tree health stakeholder analysisidentification and categorisation. Project report for Defra Projects TH0104 \& TH0107 Mapping, analysis and improved understanding of stakeholders and the public to help protect tree health

Dehnen-Schmutz K, Chas-Amil ML, Touza J (2010) Stakeholders' perceptions of plant invasions in Galicia, Spain. Asp Appl Biol 104:13-18

Dwyer J, Mills J, Ingram J, Taylor J, Burton R, Blackstock K, Slee B, Brown K, Schwarz G, Matthews K, Dilley R (2007) Understanding and influencing positive behaviour change in farmers and land managers-a project for Defra. CCRI and The Macaulay Institute

EPPO (2012) Study on the risk of imports of plants for planting. EPPO technical Document No. 1061

Everett RA (2000) Patterns and pathways of biological invasions. Tree 15(5):177-178

Firewood Outreach Coordinating Initiative (FOCI) e-newsletter (2013). http://www.dontmovefirewood.org/resources. Accessed 15 May 2013

Flint C (2006) Community perspectives on spruce beetle impacts on the Kenai Peninsula, Alaska. For Ecol Manag 227:207-218

Flint C (2007) Changing forest disturbance regimes and risk perceptions in Homer, Alaska. Risk Anal 27(6): $1597-1608$
Gagliardi JA, Brand MH (2007) Connecticut nursery and landscape industry preferences for solutions to the sale and use of invasive plants. HortTechnology 17(1):39-45

García-Llorente M, Martín-López B, González JA, Alcorlo P, Montes C (2008) Social perceptions of the impacts and benefits of invasive alien species: implications for management. Biol Conserv 141:2969-2983

Gilbert M, Fielding N, Evans HF, Grégoire J-C (2003) Spatial pattern of invading Dendroctonus micans (Coleoptera: Scolytidae) populations in the United Kingdom. Can J For Res 33:712-725

Gupta A (2010) Emerald ash borer first detector: a volunteer early detection programme. NZ J For Sci 40:123-132

Haack RA (2001) Intercepted Scolytidae (Coleoptera) at U.S. ports of entry: 1985-2000. Integr Pest Manag Rev 6:253-282

Haack RA (2006) Exotic bark- and wood-boring Coleoptera in the United States: recent establishments and interceptions. Can J For Res 36:269-288

Halford M, Heemers L, Mathys C, Vanderhieven S, Mahy G (2011) Socio-economic survey on invasive ornamental plants in Beligum. Final report for Life + AlterIAS project. http://ec.europa.eu/environment/life/project/Projects/ index.cfm?fuseaction=home .showFile $\&$ rep=file $\&$ fil $=$ ALT ERIAS_socioeco_sur_EN.pdf. Accessed July 2012

Hall CM (2005) Biosecurity and wine tourism. Tour Manag 26:931-938

Hathaway JM, Basman CM, Barro SC (2002) Assessing tree care professionals' awareness and knowledge about the Asian Longhorned Beetle. In: Van Sambeek JW, Dawson JO, Ponder F, Jr Loewenstein EF, Fralish JS (eds) Proceedings, 13th central hardwood forest conference, April 1-3, Urbana IL. Gen. Tech. Rep. NC-234. St Paul, MN: U.S. Department of agriculture, Forest Service, North Central Research Station

Holmes TP, Aukema JE, Von Holle B, Liebhold A, Sills E (2009) Economic impacts of invasive species in forests: past, present, and future. Ann N Y Acad Sci 1162:18-38

Hulme PE (2009) Trade, transport and trouble: managing invasive species pathways in an era of globalization. J Appl Ecol 46:10-18

Hunter M (2011) Impact of ecological disturbance on awareness of urban nature and sense of environmental stewardship in residential neighbourhoods. Landsc Urb Plan 101:131-138

Hurley BP, Slippers J, Wingfield MJ, Dyer C, Slippers B (2012) Perception and knowledge of the Sirex woodwasp and other forest pests in South Africa. Agric For Entomol 14:306-316

Johnson DD, Davies KW, Schreder PT, Chamberlain A-M (2011) Perceptions of ranchers about medusahead (Taeniatherum caput-medusae (L.) Nevski) management on sagebrush steppe rangelands. Environ Manag 48:400-417

Kapler EJ, Thompson JR, Widrlechner MP (2012) Assessing stakeholder perspectives on invasive plants to inform risk analysis. Invasive Plant Sci Manag 5:194-208

Kelley KM, Conklin JR, Sellmer JC, Bates RM (2006) Invasive plant species: results of a consumer awareness, knowledge and expectations survey conducted in Pennsylvania. J Environ Hortic 24(1):53-58

Kruger H, Thompson L, Clarkey R, Stenekes N, Carr A (2009) Engaging in biosecurity: gap analysis. Australian Government: Bureau of Rural Sciences 
Kruger H, Stenekes N, Clarke R, Carr A (2010) Biosecurity engagement guidelines: practical advice for involving communities. Australian Government Bureau of Rural Sciences

Kubeck G (2008) Exploring stakeholders' attitudes and beliefs regarding behaviours that prevent the spread of invasive species. A focus group study. Msc thesis, Oregon State University

Liebhold AM, Brockerhoff EG, Garret LJ, Parke JL, Britton KO (2012) Live plant imports: the major pathway for forest insect and pathogen invasions of the US. Front Ecol Environ 10(3):135-143

McEntee MJ (2007) Participation and communication approaches that influence public and media response to scientific risk: a comparative study of two biosecurity events in New Zealand. Int J Inter Soc Sci 2(4):195-203

McFarlane BL, Craig R, Stumpf-Allen G, Watson DO (2006) Public perceptions of natural disturbance in Canada's national parks: the case of the mountain pine beetle (Dendroctonus ponderosae Hopkins). Biol Conserv 130:340-348

McFarlane BL, Parking JR, Watson DOT (2012) Risk, knowledge, and trust in managing forest insect disturbance. Can J For Res 42:710-719

Molnar JJ, Schelhas J, Holeski C (2003) Controlling the southern pine beetle: small landowner perceptions and practices. Bulletin 649, Auburn University, Alabama

Müller M, Job H (2009) Managing natural disturbance in protected areas: tourists' attitudes towards the bark beetle in a German national park. Biol Conserv 142:375-383

Niemiera AX, Von Holle B (2009) Invasive plant species and the ornamental horticulture industry. In: Inderjit A (ed) Management of invasive weeds. Springer, Berlin

Parks JM, Theobald KS (2011) Public engagement with information on renewable energy developments: the case of single, semi-urban wind turbines. Public Underst Sci 22(1):49-64

Perrings C, Burgiel S, Lonsdale M, Mooney H, Willianson M (2010) International cooperation in the solution to traderelated invasive species risks. Ann NY Acad Sci 1195:198-212

Peters WL, Meyer MH, Anderson NO (2006) Minnesota horticultural industry survey on invasive plants. Euphytica 148:75-86

Pocock M, Evans D (2013) Conker tree science: public engagement and real research. In: Bowater L, Yeoman K (eds) Science Communication: a practical guide for scientists. Wiley, Chichester

Potter C, Bayliss H, Tomlinson I, Leather S (2013) Oak Processionary Moth in the UK: lessons from the London outbreak. Report to the Department of Environment, Food and Rural Affairs

Prinbeck G, Lach D, Chan S (2011) Exploring stakeholders' attitudes and beliefs regarding behaviours that prevent the spread of invasive species. Environ Educ Res 17(3): 341-352

Putulan D, Sar S, Drew RAI, Raghu S, Clarke AR (2004) Fruit and vegetable movement on domestic flights in Papua New Guinea and the risk of spreading pest fruit-flies (Diptera: Tephritidae). Int J Pest Manage 50:17-22
Quarles W (2008) Light brown apple moth: crises of trust. IPM Pract 3(4):1-13

Reichard SH, White P (2001) Horticulture as a pathway of invasive plant introductions in the United States. BioScience 51(2):103-113

Runberg DM (2011) Educating Pacific Northwest campers on the risk of spreading invasive forest pests through firewood: developing a Mental Model. Dissertation submitted for Master of Public Policy, Oregon State University. http://scholarsarchive.library.oregonstate.edu/xmlui/ handle/1957/21740. Accessed July 2013

Sacco J (2004) The attach of the urban forest eaters: how a dedicated and educated group of volunteers is responding to the invasion of Asian long-horn beetles and gypsy moths in Chicago. In: Shaw I et al (eds) Proceedings 4th international urban wildlife symposium, pp 316-324

Selge S, Fisher A, van der Wal R (2011) Public and professional views on invasive non-native species: a qualitative social scientific investigation. Biol Conserv 144:3089-3097

Sharp RL, Larson LR, Green GT (2011) Factors influencing public preferences for invasive alien species management. Biol Conserv 144:2097-2104

Sharp RL, Larson LR, Green GT, Tomek S (2012) Comparing interpretive methods targeting invasive species management at cumberland Island National Seashore. J Interpret Res 17:23-43

Slovic P, Finucane ML, Peters E, MacGregor DG (2004) Risk as analysis and risk as feelings: some thoughts about affect, reason, risk and rationality. Risk Anal 24(2):311-322

Smith RM, Baker RHA, Malumphy CP, Hammon RP, OstojáStarzewski JC, Collins DW (2007) Recent non-native invertebrate plant pest establishments in Great Britain: origins, pathways, and trends. Agric For Entomol 9:307-326

Stenlid J, Oliva J, Boberg JB, Hopkins AJM (2011) Emerging diseases in European forest ecosystems and responses in society. Forests 2:486-504

Surendra GC, Mehmood S, Schelhas J (2009) Segmenting landowners based on their information-seeking behaviour: a look at landowner education on the Red Oak Borer. J For 107:313-319

Tomlinson I, Harwood T, Knight J, Potter C (2009) Review of joint inter-departmental emergency programme to contain and eradicate Pr and Pk. Defra, London

United States Department of Agriculture (2005) Addressing the risks associated with the importation of plants for planting. A white paper (exec sum)

Van Santen L, Govern J, Langer L (2004) The role of community involvement in future incursion responses. NZ J For 49(3):38

Vanderhoeven S, Piqueray J, Halford M, Nulens G, Vinke J, Mahy G (2011) Perception and understanding of invasive alien species issues by nature conservation and horticulture professionals in Belgium. Environ Manag 47:425-442

Wachinger G, Renn O (2010) Risk perception and natural hazards. CapHaz-Net WP3 Report, DIALOGIK Nonprofit Institute for Communications and Cooperative Research, Stuttgart. (http://caphaz-net.org/outcomes-results/ CapHaz-Net_WP3_Risk-Perception.pdf)

Webber J (2010) Pest risk analysis and invasion pathways for plant pathogens. N Z J For Sci 40(suppl.):45-56 